\title{
Proposal That Flavobacterium breve Be Substituted as the Type Species of the Genus in Place of Flavobacterium aquatile and Emended Description of the Genus Flavobacterium: Status of the Named Species of Flavobacterium
}

\author{
Request for an Opinion
}

\author{
B. HOLMES AND R. J. OWEN \\ National Collection of Type Cultures, Central Public Health Laboratory, London NW9 5HT, United \\ Kingdom
}

\begin{abstract}
It is requested that the Judicial Commission issue an Opinion rejecting the name Flavobacterium aquatile (Frankland and Frankland) Bergey et al. 1923 as a nomen dubium. Because this species is the type species of the genus Flavobacterium, the Judicial Commission is also requested to issue an Opinion designating Flavobacterium breve (Lustig) Bergey et al. 1923 as the new type species of Flavobacterium. The description of the genus Flavobacterium Bergey et al. 1923 is also herein emended. The proposed taxonomic or nomenclatural status of all known previously described species of the genus Flavobacterium is indicated in appendexes to this paper.
\end{abstract}

Proposed rejection of Flavobacterium aquatile (Frankland and Frankland) Bergey et al. 1923 as the type species of Flavobacterium. Bacillus aquatilis Frankland and Frankland 1889, isolated from well water of the chalk area of Kent, was designated the type species of the genus when Flavobacterium was created in 1923 by Bergey et al. (9). However, in designating $F$. aquatile the type species, they described it as motile and peritrichous (9), a character contrary to that recorded in the original description of Bacillus aquatilis (32). This discrepancy suggests that Bergey et al. (9), in selecting the type species of Flavobacterium, may have examined peritrichous strains which they identified as $F$. aquatile, but which in fact did not belong to this species.

No type strain was designated for Bacillus aquatilis, and apparently none of the strains on which the original description of the species was based is extant. Several cultures reputed to be reisolates of $F$. aquatile were studied by Weeks (79), who found that "Cultures F39 and F36, though very different one from the other, present cultural characteristics which are superficially similar to those of the Franklands' $B$. aquatilis. It will be shown, however, that F39 is not a true bacterium. ..." The fact that two very different cultures, one of which was subsequently identified as a species of Sporocytophaga, fitted the original description of $B$. aquatilis (32) illustrates the meager and ambiguous nature of that description. Furthermore, Weeks (79) observed that culture F36 only " ... corresponds generally in its properties to those given for F. aquatile" and noted certain discrepancies between the characters of culture F36 and those given in the Franklands' original description of B. aquatilis. The colonies of culture F36 on nutrient gelatin were not composed of radiant bundles of threads, and the cells showed no movements that could be called oscillatory. Although Weeks (79) chose to discount the differential importance of these two characteristics, his arguments for doing so were based mainly on the imprecise and sometimes equivocal nature of the original description of $B$. aquatilis as given by the Franklands (32). However, one could argue equally well that these two characteristics should be given due consideration. Indeed, the original description of the species (32) as displaying oscillatory movements and filaments up to $17 \mu \mathrm{m}$ in length indicates that the organism described was probably a cytophaga or a flexibacter and not a flavobacterium at all (55). A culture of $F$. aquatile was deposited by Weeks in the American Type Culture Collection (ATCC) under the number ATCC 11947 with the strain designation Taylor F36 (1) (subsequently referred to herein as such). There is some confusion in the literature regarding the date of isolation of strain Taylor F36. Weeks and Breed (82) stated that it was isolated in 1941 whereas Weeks (79) implied that the strain was 
isolated in the early 1950s. Weeks and Beck (81) stated that their culture of "strain Taylor" was isolated in 1952, which was presumably the correct date of isolation. It has been stated in support of accepting strain Taylor F36 as a reisolate of $F$. aquatile that the strain was isolated by $\mathrm{E}$. W. Taylor from the same chalk well in Kent from which Frankland and Frankland originally isolated $B$. aquatilis (71). However, because 63 years elapsed between the original description of $B$. aquatilis and the supposed re-isolation of the species in 1952 , it would seem unlikely that E. W. Taylor could have known the exact location from which the Franklands isolated $B$. aquatilis or, if he did, the possibility of ecological changes affecting the location cannot be excluded.

The status of strain Taylor F36 was that of a lectotype [sic] according to Sneath and Skerman (71), who noted: "Clearly this strain, F36, should be made the official neotype." However, to our knowledge strain Taylor F36 has never been clearly and formally proposed as the neotype strain of $F$. aquatile, although it has become generally accepted as such (80) but never challenged until now. It is our opinion that the original description of $B$. aquatilis is too meager and incomplete for the certain assignment of strains to the species and that strain Taylor F36 cannot in any case be definitely ascribed to the species in view of its characteristics which Weeks (79) recorded to be at variance with the original description of the species.

The main cause of dissatisfaction with $F$. aquatile strain Taylor F36 as the only acceptable reference strain of the species is evidence that it might be an atypical cytophaga. Follett and Webley (31) reported that the cell wall characteristics of the strain were similar to those of Cytophaga johnsonii, whereas Mitchell et al. (59) observed that the strain actively swarmed when the cultures were incubated for prolonged periods at $15^{\circ} \mathrm{C}$. Gliding cellular motility in the strain was later demonstrated by Perry (65) using a novel microscopic technique. He (65) suggested that $F$. aquatile could be given the status of a nomen dubium because it was uncertain from the Franklands' original description (32) whether $B$. aquatilis was nonmotile or a glider. J. Henrichsen (personal communication) did not agree that strain Taylor F36 was able to glide and believed that the movements observed by Perry were attributable to some other phenomenon. There is other evidence that the strain would be misplaced in either Cytophaga or Flexibacter. Hayes (36) found that strain Taylor F36 was ungrouped and was not similar to typical cytophagas in a numerical phenetic analysis. $\mathrm{He}$ proposed that $F$. aquatile should not be retained as the type species of Flavobacterium because it did not demonstrate what he considered to be the essential characteristics of that genus. In addition, Callies and Mannheim (21) reported that strain Taylor F36 contains ubiquinones and therefore is different from the flavobacteria and cytophagas which have a low guanine plus cytosine $(\mathrm{G}+\mathrm{C})$ content in their deoxyribonucleic acid (DNA) and which have menaquinones as their sole respiratory quinones.

$F$. aquatile was an unfortunate choice as the type species of Flavobacterium because the species is currently represented by only one strain which is of uncertain taxonomic affinities. McMeekin and Shewan (55) consider that a fuller species description is required and that attempts should be made to isolate further strains of the organism. However, we reject such an approach because on their own admission (55) " ... retention of $F$. aquatile as the type species is of doubtful value and will continue to present difficulties." The consequences of retaining the species should be considered. If strain Taylor F36 is subsequently proved to be a cytophaga and becomes established as the neotype of Flavobacterium aquatile, then the species would probably have to be classified with species of Flexibacter. Because the name Flavobacterium was published before Flexibacter, the former would take priority, all of the current species of Flexibacter would become species of Flavobacterium, and a new genus would have to be erected to accommodate the remaining currently known species of Flavobacterium. Acceptance of strain Taylor F36 as a strain of $F$. aquatile could thus result in causing more widespread taxonomic confusion than already exists in the genus Flavobacterium.

In consideration of the foregoing, we request that the Judicial Commission issue an Opinion rejecting the name Flavobacterium aquatile (Frankland and Frankland) Bergey et al. 1923 as a nomen dubium as has been previously suggested (65).

Proposal that Flavobacterium breve (Lustig) Bergey et al. 1923 be designated the type species of Flavobacterium. F. breve was included in the original description of the genus Flavobacterium and apart from $F$. aquatile was the only original species retained by Weeks (80) in section $I$ of the genus. We believe that $F$. breve would be a more appropriate choice than $F$. aquatile as the type species of Flavobacterium. A neotype strain (NCTC 11099) has been proposed for $F$. breve, and the description of the species has recently been revised (41). It is more typical of a group of similar bacteria widely placed under the genus name than is $F$. aquatile, and there are more strains of this species avail- 
able for study: at least 10 strains have now been identified in our laboratory, and these include three further reference cultures of $F$. breve deposited in culture collections-NCTC 11162, NCTC 11163, and ATCC 14234. The original description of $F$. breve, like that of $F$. aquatile, was rather meager, and none of the strains on which the original description was based are extant. However, when the description of $F$. breve was revised (41) on the basis of subsequent isolates, there were no consistent discrepancies between these isolates and the original description given by Lustig (53) and there was no evidence of affinity to the cytophagas, a fact confirmed by L. Perry (personal communication). Of those species listed below in Appendix I, only $F$. meningosepticum contains strains on which the original description of the species was based. $F$. balustinum, $F$. meningosepticum, and $F$. odoratum were excluded as candidates to replace $F$. aquatile as the type species because they were not species included in the genus when the genus description was originally published (9). Therefore we request that the Judicial Commission issue an Opinion designating Flavobacterium breve as the new type species of the genus Flavobacterium.

Emendation of the description of the genus Flavobacterium Bergey et al. 1923. The main criteria for including a species in the genus Flavobacterium as originally described by Bergey et al. (9) were the formation of yellow- or orange-pigmented colonies on culture media and the ability to produce acid weakly from carbohydrates. Because Flavobacterium was based on so few characteristics, the genus was taxonomically heterogeneous from the beginning and was considered by Weeks $(80)$ to be an uncertain taxonomic concept. As originally described, the genus contained gram-negative species that were peritrichous, polarly flagellated, or nonmotile as well as some gram-positive species. The degree of heterogeneity in the genus was subsequently reduced by excluding species in which strains were either polarly flagellated (8) or definitely gram-positive (82). As defined by Weeks (80), the genus also excluded species which showed gliding or swarming on culture media. It was divided into two sections: section I contained nonmotile species with the $\mathrm{G}+\mathrm{C}$ content of their DNA in the range of 30 to $42 \mathrm{~mol} \%$ (low-G+Ccontent strains) and section II contained species that were either nonmotile or motile and peritrichous but that had $\mathrm{G}+\mathrm{C}$ contents in the range of 63 to $70 \mathrm{~mol} \%$ (high-G+C-content strains).

The definitions of Flavobacterium given in the various editions of Bergey's Manual of Determinative Bacteriology were not necessarily generally accepted. In the view of Ferrari and
Zannini (30), gram-positive strains should not be excluded because of the variability in the Gram reaction of some species. Brisou (16) proposed that the nonmotile species be placed in a new genus called Empedobacter and retained the peritrichous strains in Flavobacterium, although at that time the $\mathrm{G}+\mathrm{C}$ contents of strains to be included in the former genus were not known. Another approach was to view the nonmotile, low-G+C-content strains of Flavobacterium as probable cytophagas (59), typical cytophagas being strains that exhibited true gliding motility and spreading growth (25). Although evidence to support this approach was reported by Perry (65), the interpretation of his observations has been questioned by other workers, notably J. Henrichsen (personal communication) and McMeekin and Shewan (55). Further evidence of the overlap between Flavobacter. ium and Cytophaga was provided by Christensen (24), who concluded from a comprehensive phenotypic study that $F$. pectinovorum, a socalled atypical cytophaga, was identical with $C$. johnsonae. However, not all Flavobacterium species should necessarily be regarded as misplaced cytophagas because cellular movements by non-flagellated bacteria are sometimes difficult to demonstrate and to interpret $(25,56)$. Hayes (36) and McMeekin et al. (57) showed in phenetic analyses that although there were few unequivocal distinguishing tests, typical cytophagas were generally distinguishable from nonmotile, nongliding strains with low $\mathrm{G}+\mathrm{C}$ contents. Hayes (36) believed that the latter should be retained in Flavobacterium, whereas gramnegative, nonmotile or motile and peritrichous, high-G+C-content species of Flavobacterium could possibly be reclassified in Empedobacter. More recently, Callies and Mannheim (21) found that flavobacteria either possessed ubiquinones or menaquinones as their sole respiratory quinones and proposed that the genus Flavobacterium should be restricted to those low-G+C-content strains containing ubiquinones, thus resembling $F$. aquatile.

Various gram-negative, nonmotile, nongliding, nonspreading, low-G+C-content strains from soil and water $(35,36,60)$, food products and processing plants $(4,36,52)$, and human clinical specimens and the hospital environment $(44,60$, $61,66,76,77)$ have been identified as flavobacteria. Few of these isolates were ascribed to species, possibly because of the inadequate definition of Flavobacterium and the lack of suitable reference strains. We believe, therefore, that the description of Flavobacterium given by Weeks $(80)$ should be emended. Various strategies for the taxonomic revision of flavobacteria were discussed by McMeekin and Shewan (55), 
and their conclusion with regard to Flavobacterium was: "5. Low \% GC non-motile, nongliding organisms represent the majority of Gram negative yellow pigmented strains and should be allocated to the genus Flavobacterium...." This view agrees with ours, and it is one that has apparently been increasingly adopted in recent years by microbiologists in various fields. From the standpoint of medical microbiology, we believe it is important that the name Flavobacterium be conserved for the gram-negative, nonmotile, nongliding, nonspreading strains with low $\mathrm{G}+\mathrm{C}$ contents; otherwise well-described and medically important species such as $F$. breve, $F$. meningosepticum, and $F$. odoratum might have to be reclassified. It does not seem advantageous at present to transfer these species, for which there are designated type strains, to other relatively poorly understood genera such as Cytophaga, Empedobacter, or Flexibacter, or, alternatively, to create a new genus for these species.

Accordingly the following emended description of the genus Flavobacterium is proposed. This description is based primarily on our results (40-42, 45, 61-63) for clinical isolates. However, to avoid a bias towards isolates of clinical origin, the results of Hayes $(36,37)$ are also taken into account because several of Hayes' strains corresponded to species recognized in our laboratory and were isolated from a variety of nonclinical sources. Likewise, we have also included results from Callies and Mannheim (21) on the respiratory quinones.

Flavobacterium Bergey et al. emend. Cells vary in shape from rods to near coccal forms; long rods often develop in liquid media. Nonmotile. Do not glide or spread (swarm) on a nutrient agar medium. Endospores not formed. Gram negative.

Growth on solid media is typically pigmented (yellow to orange), but some strains may be nonpigmented. The pigment hue may vary with the growth medium and the incubation period. The degree of pigmentation may be more pronounced at lower temperatures $\left(15\right.$ to $20^{\circ} \mathrm{C}$ ), and daylight may be required for the development of maximum pigmentation. The pigments are nonfluorescent and are insoluble in growth media; they are generally presumed to be carotenoid. Colonies are typically translucent (occasionally opaque), circular, convex or low convex, smooth and shiny with entire edges.

Chemoorganotrophic. Generally not fastidious, but some cultures may prove difficult to maintain following primary isolation. $\mathrm{NaCl}$ is not required at concentrations in excess of $10 \%$ (wt/vol).

Metabolism is respiratory. Menaquinones are the sole respiratory quinones. Aerobic; unable to grow anaerobically in an atmosphere of pure hydrogen (they may grow anaerobically in the presence of $7 \%$ [vol/vol] carbon dioxide and consequently may be mistaken for facultative anaerobes). Neither acid nor gas is produced from carbohydrates in peptone water or broth media. Those strains dissimilating glucose do so oxidatively with the production of acid only, and then only when the concentrations of peptone in the test media are low. Other carbohydrates most frequently attacked are fructose, glycerol, maltose, and trehalose.

The temperature range for the growth of environmental isolates is usually 0 to $30^{\circ} \mathrm{C}$, clinical isolates grow at $37^{\circ} \mathrm{C}$, and in some species strains grow at $42^{\circ} \mathrm{C}$.

Generally actively proteolytic, the majority of strains digest casein and liquefy gelatin. Extracellular deoxyribonuclease is produced by most strains. Tributyrin is often hydrolyzed. Catalase, oxidase, and phosphatase are produced. Citrate is not utilized. Amino acids, supplementary growth factors, or both, particularly aneurine or biotin, may be required for growth. Indole is often produced in small amounts (a sensitive technique is necessary to demonstrate this character). Agar is not digested.

Widely distributed in soil and water. Commonly found in food such as raw meats (including poultry), vegetables during commercial processing, and dairy products. Occur in the hospital environment and in human clinical material. Some strains are pathogenic for man and other animals, while others are probably opportunist pathogens.

The $\mathrm{G}+\mathrm{C}$ content of the DNA ranges from 31 to $40 \mathrm{~mol} \%$.

Status of previously described species of Flavobacterium. During our reappraisal of the characteristics of the genus Flavobacterium, a comprehensive list was prepared of the names of all of the described species of Flavobacterium. Certain species (Appendix I) are acceptable under the proposed redescription of the genus Flavobacterium. Other species are excluded from the genus Flavobacterium because they either are of unknown status and there are no extant reference strains (Appendix II) or do not conform to the emended description (Appendix III). In Appendix IV are listed the species that were originally placed in Flavobacterium but were later transferred to other genera. Appendix V contains species names which are not validly published according to the Bacteriological Code (46).

Although Flavobacterium devorans (Zimmermann) Bergey et al. 1923 is included in Appendix III because there is a reference strain for 
the species-ATCC 10829-this strain has recently been found by E. Yabuuchi, E. Tanimura, A. Ohyama, I. Yano and A. Yamamoto (Abstracts of the XII International Congress for Microbiology, Munich, p. 90, 1978) and E. Falsen (personal communication) to belong to Pseudomonas paucimobilis (39). Consequently it is possible that someone might cause confusion by suggesting that $P$. paucimobilis is a junior synonym of $F$. devorans and then proposing the new combination Pseudomonas devorans for $P$. paucimobilis. We would formally challenge any such proposal because the original description of $F$. devorans, like that of $F$. aquatile, is meager and incomplete so that unequivocal identification of strains of the species, based on the original description as reference, is not possible. Also, ATCC 10829, which Yabuuchi et al.(Abstracts of the XII International Congress for Microbiology, p. 90, 1978) found to be motile by means of a single polar flagellum, does not conform neatly either to the description of the species given by Weeks (80), wherein it is claimed to be peritrichous, or to the original description of the species (83). Zimmermann (83) described Bacillus devorans as being extremely motile whereas, motility is difficult to demonstrate in strains of $P$. paucimobilis, as the name is intended to show. $B$. devorans colonies on gelatin were said to be only yellowish-gray, whereas colonies of $P$. paucimobilis are clearly deeply yellow pigmented (39; Yabuuchi et al., Abstracts of the XII International Congress for Microbiology, p. 90, 1978). We endorse the statement by Yabuuchi et al. (Abstracts of the XII International Congress for Microbiology, p. 90, 1978) that: "Unless the authentic strain of the original describer for $F$. devorans or any isolate in conformity with the original description for the species is found, the name Flavobacterium devorans should not be retained further." We therefore consider that $F$. devorans should not be on the Approved Lists of Bacterial Names when they are published on January 1, 1980.

\section{APPENDIX I}

The following appear to be acceptable as species of Flavobacterium.

\begin{tabular}{|c|c|c|}
\hline Species & Type or reference strains & Reference \\
\hline Flavobacterium balustinum & $\begin{array}{l}\text { NCTC } 11212 \\
=\text { La } 724^{a}\end{array}$ & Harrison 1929 (34) \\
\hline Flavobacterium breve & $\begin{array}{l}\text { NCTC } 11099 \\
\text { NCTC } 11162 \\
\text { NCTC } 11163 \\
\text { ATCC } 14234\end{array}$ & Lustig 1890 (53) \\
\hline $\begin{array}{l}\text { Flavobacterium meningosepti- } \\
\quad \text { cum }\end{array}$ & $\begin{array}{l}\text { NCTC } 10016 \\
=\text { ATCC } 13253 \\
\text { (serotype } A \text { ) } \\
\text { NCTC 10585 } \\
=\text { ATCC } 13254 \\
\text { (serotype } B \text { ) } \\
\text { NCTC } 10586 \\
=\text { ATCC } 13255 \\
\text { (serotype } C \text { ) } \\
\text { NCTC 10587 } \\
\text { (serotype } D \text { ) } \\
\text { NCTC } 10588 \\
\text { (serotype } E \text { ) } \\
\text { NCTC } 10589 \\
\text { (serotype } F \text { ) }\end{array}$ & King 1959 (44) \\
\hline Flavobacterium odoratum & $\begin{array}{l}\text { NCTC } 11036 \\
=\text { ATCC } 4651 \\
\text { NCTC } 11179 \\
=\text { ATCC } 29979 \\
\text { NCTC } 11180\end{array}$ & $\begin{array}{l}\text { Stutzer and Kwaschnina } 1929 \\
\quad(75)\end{array}$ \\
\hline
\end{tabular}

\footnotetext{
${ }^{a}$ We have examined this strain in our laboratory and have found that it corresponds to the herein emended description of the genus Flavobacterium. We are preparing a revised description of the species, and we will be proposing a neotype strain for the species. Abbreviations: ATCC, American Type Culture Collection, Rockville, Md.; NCTC, National Collection of Type Cultures, London, England.
} 


\section{APPENDIX II}

There are no known extant reference strains for the following species which have been placed in the genus Flavobacterium. The status of these species is therefore unknown. It is possible that some of these species could be excluded from the genus Flavobacterium on characteristics given in their original descriptions. However, in view of the lack of reference cultures, we suggest that these names should not appear on the Approved List of Bacterial Names, which becomes effective on January 1, 1980. Accordingly we have neither examined the original descriptions nor given references. Names and citations are taken from Index Bergeyana (19).

F. aestumarina (ZoBell and Upham) Brisou 1955

F. amocontactum ZoBell and Allen 1935

F. amylum Morris 1946

F. androstendionicum Ercoli and Molina 1944

F. annulatum (Chester) Bergey et al. 1923

$F$. antenniforme (Ravenel) Bergey et al. 1923

F. aromaticum (Pammel) Bergey et al. 1923

F. aurantinum (Hammer) Bergey et al. 1923

F. aurescens (Ravenel) Bergey et al. 1923

F. boreale (Lundestad) Bergey et al. 1930

F. brunneum (Copeland) Bergey et al. 1923

$F$. butyri Bergey et al. 1923

F. carbonilicum Molina and Ercoli 1944

F. ceramicola (Lundestad) Bergey et al. 1930

F. cerevisiae (Fuhrmann) Bergey et al. 1923

F. chitinochroma (Hock) Brisou 1955

F. chlorum Steinhaus 1941

F. deciduosum (Wright) Bergey et al. 1923

$F$. delesseriae (Lundestad) Bergey et al. 1930

F. diffusum (Frankland and Frankland) Bergey et al. 1923

F. dormitator (Wright) Bergey et al. 1923

F. droebachense (Lundestad) Bergey et al. 1930

F. flavotenue Schrire 1928

F. flavum (Fuhrmann) Bergey et al. 1923

F. fucatum Harrison 1929

F. fulvum (Zimmermann) Bergey et al. 1923

$F$. gelatinum Sanborn 1930

F. granulatum Ferrari and Zannini 1958

F. (Halobacterium) maris-mortui [sic] Elazari-Volcani 1940

F. halohydrium ZoBell and Upham 1944

$F$. halophilum Bergey et al. 1930

F. iniquum Stapp 1940

$F$. invisible (Vaughan) Bergey et al. 1923

$F$. kornii (Chester) Hauduroy et al. 1953

F. lacunatum (Wright) Bergey et al. 1923

F. lutzii (Brown) Brown and Heffron 1929

F. marinum Harrison 1929

F. matzoonii (Chester) Bergey et al. 1923

$F$. meningitidis Hauduroy et al. 1937

F. morbificans (Migula) Bergey et al. 1930

F. neptunium ZoBell and Upham 1944

$F$. ochraceum (Zimmermann) Bergey et al. 1923

F. orchiditis [sic] Sherwood, Irwin, and Marts 1933

F. ovale (Wright) Bergey et al. 1923

$F$. peregrinum Stapp and Spicher 1954

F. plicatum (Copeland) Bergey et al. 1923

$F$. polysiphoniae (Lundestad) Bergey et al. 1930

F. pruneaeum [sic] Sanborn 1930

F. racemosum (Zettnow) Bergey et al. 1923

F. radiatum (Zimmermann) Bergey et al. 1923

$F$. rhodomelae (Lundestad) Bergey et al. 1930

$F$. schirokikhii (Jensen) Bergey et al. 1923

F. sinuosum Ferrari and Zannini 1958

F. stolonatum (Adametz and Wichmann) Bergey et al. 1923

F. tabidum Kimata 1942

F. tremelloides (Tils) Bergey et al. 1923

F. turcosum (Zimmermann) Bergey et al. 1923

F. ustilagophagum [sic] Cercos 1948

$F$. vadosa [sic] (ZoBell and Upham) Brisou 1955

$F$. vaginale Hosoya and Onoda 1954

$F$. vitarumen Bechdel, Honeywell, Dutscher, and Knutsen 1928

F. xanthochrus [sic] (ZoBell and Upham) Brisou 1955 


\section{APPENDIX III}

The following species, until now assigned to Flavobacterium and for which there are extant reference strains, are excluded from the genus because they do not conform to the description of the genus Flavobacterium as it is herein emended. Culture collection accession numbers are quoted for reference cultures (ATCC = American Type Culture Collection, Rockville, Md.; CCEB = Czechoslovak Collection of Entomogenous Bacteria [Institute of Entomology], Prague, Czechoslovakia; NCMB = National Collection of Marine Bacteria, Torry Research Station, Aberdeen AB9 8DG, Scotland; CCM = Czechoslovak Collection of Microorganisms, J. E. Purkynĕ University, Brno, Czechoslovakia; NCIB = National Collection of Industrial Bacteria, Aberdeen, AB9 8DG, Scotland; ETH = Mikrobiologisches Institut, Eidgenössische Technische Hochschule, CH-8006 Zürich, Switzerland; NCTC = National Collection of Type Cultures, Central Public Health Laboratory, London NW9 5HT, England; $\mathrm{La}=$ International Center for Information on and Distribution of Type-Cultures, CH-1000 Lausanne 17, Switzerland).

\section{Species}

F. acidificum Steinhaus 1941 (74) (ATCC 8366; type strain)

F. acidurans Millar 1973 (58) (ATCC 27383; type strain)

$F$. arborescens (Frankland and Frankland) Bergey et al. 1923 (9) (ATCC 4358)

$F$. aurantiacum (Frankland and Frankland) Bergey et al. 1923 (9) (CCEB 304)

F. buccalis (Chester) Bergey et al. 1923 (9) (University of Surrey 401)

F. capsulatum Leifson 1962 (47) (ATCC 14666; type strain)

F. caudatum (Wright) Bergey et al. 1923 (9) (NCMB 1499)

F. dehydrogenans (Arnaudi) Arnaudi 1942 (2) (ATCC 13930)

F. denitrificans (Jensen) Bergey et al. 1923 (9) (CCM 1950)

F. devorans (Zimmermann) Bergey et al. 1923 (9) (ATCC 10829)

F. enalia [sic] (ZoBell and Upham) Brisou 1955 (15) (ATCC 23821 Alteromonas haloplanktis)

F. esteroaromaticum (Omelianski) Bergey et al. 1930 (10) (ATCC 8091)

F. extorquens (Bassalik) Bassalik, Janota-Bassalik and Brisou 1960 (3) (NCIB 9399)

F. ferrugineum Sickles and Shaw 1934 (70) (ATCC 13524)

F. flavescens (Pohl) Bergey et al. 1923 (9) (ATCC 8315)

F. halmephilum Elazari-Volcani 1940 (B. Elazari-Volcani, Ph.D. thesis, the Hebrew University, Jerusalem, Israel, 1940) (ATCC 19717)

$F$. harrisonii (Buchanan and Hammer) Bergey et al. 1923 (9) (ATCC 14589 Erwinia herbicola)

F. heparinum Payza and Korn 1956 (64) (ATCC 13125)

F. indoltheticum Campbell and Williams 1951 (22) (ATCC 27950, type strain)

F. lactis (Grimm) Bergey et al. 1923 (9) (ETH 4078)

" $F$. lucecoloratum" (unpublished name) (ATCC 17964)

F. lutescens (Migula) Bergey et al. 1923 (9) (2611 Brisou)

F. marinotypicum ZoBell and Upham 1944 (84) (ATCC 19260, type strain)
Present generic status or reason for rejection (from original description if no reference is given), or both

Motile. Reference culture gram positive (80)

DNA base composition is $66.3 \mathrm{~mol} \% \mathrm{G}+\mathrm{C}$

Reference culture gram positive; DNA base composition is $71 \mathrm{~mol} \% \mathrm{G}+\mathrm{C}(80)$

Motile. Peritrichous and "Gram labile" according to CCEB records

DNA base composition is $51.1 \mathrm{~mol} \% \mathrm{G}+\mathrm{C}$ (NCTC unpublished data)

DNA base composition is $63 \mathrm{~mol} \% \mathrm{G}+\mathrm{C}(59)$

Reisolated in 1919 by Conn (26), who described it as motile and transferred it to Pseudomonas

Gram positive. DNA base composition is 72 to 74 $\mathrm{mol} \% \mathrm{G}+\mathrm{C}(80)$

Motile

Motile. DNA base composition is $69 \mathrm{~mol} \% \mathrm{G}+\mathrm{C}(80)$. Reference strain identified as Pseudomonas paucimobilis (Yabuuchi et al. Abstracts of the XII International Congress for Microbiology, Munich, p. 90)

Motile by means of several flagella at each pole

Reference strain is gram positive; DNA base composition is $69 \mathrm{~mol} \% \mathrm{G}+\mathrm{C}(80)$

Polarly flagellated

DNA base composition is $48.6 \mathrm{~mol} \% \mathrm{G}+\mathrm{C}$ (NCTC unpublished data; cf value of Weeks, $42.6 \mathrm{~mol} \% \mathrm{G}+\mathrm{C}$ [80])

Motile. Reference strain is gram positive; DNA base composition is $71 \mathrm{~mol} \% \mathrm{G}+\mathrm{C} \mathrm{(80)}$

DNA base composition is $49.7 \mathrm{~mol} \% \mathrm{G}+\mathrm{C} \mathrm{(21)}$

Peritrichous

Motile. DNA base composition is $45.6 \mathrm{~mol} \% \mathrm{G}+\mathrm{C}(65)$

Peritrichous

Peritrichous

Gram variable and motile, according to ATCC records

DNA base composition is $65 \mathrm{~mol} \% \mathrm{G}+\mathrm{C}(80)$

Peritrichous 
APPENDIX III-Continued

\begin{tabular}{|c|c|}
\hline Species & $\begin{array}{l}\text { Present generic status or reason for rejection (from original } \\
\text { description if no reference is given), or both }\end{array}$ \\
\hline $\begin{array}{l}\text { F. marinovirosum ZoBell and Upham } 1944 \text { (84) } \\
\text { (NCMB 563) }\end{array}$ & Peritrichous \\
\hline $\begin{array}{l}\text { F. oceanica [sic] (ZoBell and Upham) Brisou } 1955 \\
\text { (15) (NCMB 558) }\end{array}$ & $\begin{array}{l}\text { Motile by means of a single flagellum at one or at each } \\
\text { pole }\end{array}$ \\
\hline $\begin{array}{l}\text { F. oceanosedimentum Carty and Litchfield } 1978 \text { (23) } \\
\text { (ATCC 31317) }\end{array}$ & DNA base composition is $67.5 \mathrm{~mol} \% \mathrm{G}+\mathrm{C}$ \\
\hline $\begin{array}{l}\text { F. okeanokoites ZoBell and Upham } 1944 \text { (84) (CCM } \\
320 \text { ) }\end{array}$ & Peritrichous \\
\hline “F. oxydans" (unpublished name) (ATCC 21245) & $\begin{array}{l}\text { Gram positive and probably a Corynebacterium sp. } \\
\text { according to ATCC records }\end{array}$ \\
\hline $\begin{array}{l}\text { F. pictorum Brisou, Tysset, and Jacob } 1960 \text { (17) (La } \\
730 \text { ) }\end{array}$ & Motile \\
\hline $\begin{array}{l}\text { F. resinovorum Delaporte and Daste } 1956 \text { (27) (ATCC } \\
12524 \text { ) }\end{array}$ & Peritrichous \\
\hline F. rigense Bergey et al. 1923 (9) (F18 Weeks) & Peritrichous \\
\hline $\begin{array}{l}F \text {. sewanense (Kalantarian and Petrosian) Bergey et } \\
\text { al. } 1934 \text { (7) (La 734) }\end{array}$ & $\begin{array}{l}\text { DNA base composition is } 66.7 \mathrm{~mol} \% \mathrm{G}+\mathrm{C} \text { (NCTC } \\
\text { unpublished data) }\end{array}$ \\
\hline $\begin{array}{l}\text { F. solare (Lehmann and Neumann) Bergey et al. } 1923 \\
\text { (9) (NCMB 692) }\end{array}$ & Gram-positive according to NCMB records \\
\hline F. suaveolens Soppeland 1924 (72) (ATCC 958) & $\begin{array}{l}\text { Peritrichous. Reference strain is gram positive and has } \\
\text { a DNA base composition of } 70 \mathrm{~mol} \% \mathrm{G}+\mathrm{C}(80)\end{array}$ \\
\hline $\begin{array}{l}\text { F. tirrenicum Marini and Spalla } 1964 \text { (54) (ATCC } \\
\text { 15997) }\end{array}$ & Motile \\
\hline $\begin{array}{l}\text { F. trifolii (Huss) Bergey et al. } 1923 \text { (9) (ATCC } 14537 \\
\text { Erwinia herbicola) }\end{array}$ & Polarly flagellated \\
\hline $\begin{array}{l}\text { F. uliginosum ZoBell and Upham } 1944 \text { (84) (ATCC } \\
\text { 14397) }\end{array}$ & Agarolytic \\
\hline $\begin{array}{l}\text { F. xanthium [sic] (Zettnow) Bergey et al. } 1930 \text { (10) } \\
\text { (ATCC 8375) }\end{array}$ & Polarly flagellated \\
\hline
\end{tabular}

\section{APPENDIX IV}

The following species, for which there are extant reference strains, were originally assigned to Flavobacterium, but have since been transferred to other genera by various authors. These species are excluded from the genus because they do not conform to the description of the genus Flavobacterium as it is herein emended. Culture collection accession numbers are quoted for reference strains (for abbreviations, see head of APPENDIX III)

Species Present generic status or reason for rejection (from original

F. acetylicum Levine and Soppeland 1926 (49) (ATCC 953, ATCC 954)

F. coeliacum (Gray and Thornton) Bergey et al. 1930 (10) (ATCC 17041, type strain)

F. fecale Bergey et al. 1930 (10) (NCTC 11036, proposed neotype for $F$. odoratum)

$F$. fermentans (von Wolzogen Kühr) Bergey et al. 1934 (7) (NCTC 8049, neotype of $A$. hydrophila)

F. fuscum (Zimmermann) Bergey et al. 1923 (9) (B. fuscum: ATCC 15993; $F$. fuscum: ATCC 14233, ATCC 25310)

F. (Halobacterium) cutirubrum [sic] (Lochhead) Elazari-Volcani 1940 (B. Elazari-Volcani, Ph.D. thesis, the Hebrew University, Jerusalem, Israel, 1940) (CCM 2088)

F. (Halobacterium) halobium [sic] (Petter) ElazariVolcani 1940 (Ph.D. thesis) (CCM 2090)

F. (Halobacterium) salinarium [sic] (Harrison and Kennedy) Elazari-Volcani 1940 (Ph.D. thesis) (CCM 2084)
Gram positive. Brevibacterium Breed 1957 (13)

Gram positive. Nocardia Waksman and Henrici 1948 (78)

Illegitimate, junior synonym of $F$. odoratum (40)

Polarly flagellated. Junior synonym of Aeromonas hydrophila Stanier 1943 (73)

Gram positive. Brevibacterium Breed 1953 (12)

Subjective synonym of Halobacterium salinarium (33)

Polarly flagellated (33), requires added $\mathrm{NaCl}$ in concentrations in excess of $10 \%$ (wt/vol); transferred to Halobacterium by Elazari-Volcani 1957 (29)

Two flagella, one at each pole. Requires added $\mathrm{NaCl}$ in concentrations in excess of $10 \%$ (wt/vol); transferred to Halobacterium by Elazari-Volcani 1957 (29) 
APPENDIX IV-Continued

\begin{tabular}{|c|c|}
\hline Species & $\begin{array}{l}\text { Present generic status or reason for rejection (from original } \\
\text { description if no reference is given), or both }\end{array}$ \\
\hline $\begin{array}{l}\text { F. (Halobacterium) trapanicum [sic] (Petter) Elazari- } \\
\text { Volcani } 1940 \text { (Ph.D. thesis) (NCMB 767) }\end{array}$ & $\begin{array}{l}\text { Requires added } \mathrm{NaCl} \text { in concentrations in excess of } \\
10 \% \text { (wt/vol); transferred to Halobacterium by Ela- } \\
\text { zari-Volcani } 1957 \text { (29) }\end{array}$ \\
\hline $\begin{array}{l}\text { F. helvolum (Zimmermann) Bergey et al. } 1923 \text { (9) } \\
\text { (ATCC 11822) }\end{array}$ & Gram positive. Brevibacterium Lochhead 1955 (50) \\
\hline F. lasseuri Bergey et al. 1930 (10) (ATCC 12983) & $\begin{array}{l}\text { Illegitimate, junior synonym of Pseudomonas lemon- } \\
\text { nieri (Lasseur) Breed } 1948 \text { (11) }\end{array}$ \\
\hline F. maris Harrison 1929 (34) (ATCC 21111) & erium Breed 1953 (12) \\
\hline $\begin{array}{l}F \text {. pectinovorum Dorey } 1959 \text { (28) (ATCC 19366, type } \\
\text { strain) }\end{array}$ & Subjective synonym of Cytophaga johnsonae (24) \\
\hline F. piscicida Bein 1954 (5) (ATCC 15251) & $\begin{array}{l}\text { Peritrichous. Pseudomonas Buck, Meyers, and Leif- } \\
\text { son } 1963(20)\end{array}$ \\
\hline $\begin{array}{l}\text { F. proteus Shimwell and Grimes } 1936 \text { (69) (ATCC } \\
\text { 12841) }\end{array}$ & $\begin{array}{l}\text { DNA base composition is } 48 \mathrm{~mol} \% \mathrm{G}+\mathrm{C}(67) \text {; Obes- } \\
\text { umbacterium Shimwell } 1963(68)\end{array}$ \\
\hline $\begin{array}{l}\text { F. pseudomallei (Whitmore) Bergey et al. } 1930 \text { (10) } \\
\text { (ATCC 15682) }\end{array}$ & Motile. Pseudomonas Haynes 1957 (38) \\
\hline $\begin{array}{l}\text { F. rhenanus [sic] (Migula) Bergey and Breed } 1948 \text { (6) } \\
\text { (CCM 298) }\end{array}$ & Motile. Subjective synonym of Erwinia herbicola (48) \\
\hline $\begin{array}{l}\text { F. rhenii (Chester) Bergey et al. } 1923(9) \text { (F. rhenanum } \\
\text { CCM 298) }\end{array}$ & $\begin{array}{l}\text { Illegitimate, junior synonym of Flavobacterium rhen- } \\
\text { anum (Migula) Bergey and Breed } 1948 \text { (6) }\end{array}$ \\
\hline $\begin{array}{l}F \text {. salmonicolor (den Dooren de Jong) Bergey et al. } \\
1930 \text { (10) (ATCC 19149) }\end{array}$ & $\begin{array}{l}\text { Gram positive. Nocardia Waksman and Henrici } 1948 \\
\text { (78) }\end{array}$ \\
\hline F. sulfureum Bergey et al. 1923 (9) (ATCC 19098) & Gram positive. Brevibacterium Breed 1957 (13) \\
\hline $\begin{array}{l}F . \text { synxanthum (Ehrenberg) Bergey et al. } 1923 \text { (9) } \\
\text { (ATCC } 9890, \text { suggested neotype) }\end{array}$ & Flagellated. Pseudomonas Breed 1948 (14) \\
\hline $\begin{array}{l}\text { F. zettnowii Bergey et al. } 1923 \text { (9) (ATCC } 8375 P \text {. } \\
\text { xanthe) }\end{array}$ & $\begin{array}{l}\text { Illegitimate, junior synonym of Pseudomonas xantha } \\
\text { Zettnow } 1915 \text { (19) }\end{array}$ \\
\hline
\end{tabular}

\section{APPENDIX V}

The following names of species of Flavobacterium are considered to be not validly published according to the rules of the Bacteriological Code (46).

F. nubilum

F. thermophilum

\section{ACKNOWLEDGMENTS}

Although the major reference sources used were Bergey's Manual of Determinative Bacteriology (18), Index Bergeyana (19), and our own previously published work, we thank W. W. Leveritt of the World Data Center for Microorganisms for supplying us with an up-to-date list of cultures of Flavobac. terium species maintained in Culture Collections. We are grateful to Helen T. Westmancoat for translation of the original German descriptions of several species. We thank K. D. Phillips for determining the gaseous requirements of a set of representative cultures.

\section{REPRINT REQUESTS}

Address reprint requests to: B. Holmes, National Collection of Type Cultures, Central Public Health Laboratory, London, NW9 5HT, England.

\section{LTERATURE CITED}

1. American Type Culture Collection. 1978. Catalogue of strains I, 13th ed., p. 80. American Type Culture Collection, Rockville, Md.

2. Arnaudi, C. 1942. Flavobacterium dehydrogenans (Micrococcus dehydrogenans) und seine Fähigkeit zur Oxydation von Steroiden sowie Substanzen aus der Sexualhormonreihe. Zentralbl. Bakteriol. Parasitenkd. Infektionskr. Abt. 2 105:352-366.

3. Bassalik, C., L. Janota-Bassalik, and J. Brisou. 1960.
(Frankland and Frankland) Jensen 1934 (43)

Loginova, Userbayeva, and Egorova 1978 (51)

Étude sur Flavobacterium extorquens (ex. Pseudomonas extorquens). Ann. Inst. Pasteur Paris 98:165-169.

4. Bean, P. G., and J. R. Everton. 1969. Observations on the taxonomy of chromogenic bacteria isolated from cannery environments. J. Appl. Bacteriol. 32:51-59.

5. Bein, S. J. 1954. A study of certain chromogenic bacteria isolated from "red tide" water with a description of a new species. Bull. Mar. Sci. Gulf Caribb. 4:110-119.

6. Bergey, D. H., and R. S. Breed. 1948. Genus III. Flavobacterium Bergey et al., p. 427. In R. S. Breed, E. G. D. Murray, and A. P. Hitchens (ed.), Bergey's manual of determinative bacteriology, 6 th ed. Baillière, Tindall $\&$ Cox, London.

7. Bergey, D. H., R. S. Breed, B. W. Hammer, F. M. Huntoon, E. G. D. Murray, and F. C. Harrison (ed.). 1934. Genus II. Flavobacterium Bergey et al., 1923, p. 135. In Bergey's manual of determinative bacteriology, 4th ed. Baillière, Tindall \& Cox, London.

8. Bergey, D. H., R. S. Breed, E. G. D. Murray, and A. P. Hitchens (ed.). 1939. Genus VI. Flavobacterium Bergey et al., p. 522. In Bergey's manual of determinative bacteriology, 5th ed. Baillière, Tindall \& Cox, London.

9. Bergey, D. H., F. C. Harrison, R. S. Breed, B. W. Hammer, and F. M. Huntoon (ed.). 1923. Genus II. Flavobacterium gen. nov., p. 97. In Bergey's manual of determinative bacteriology. The Williams \& Wilkins Co., Baltimore. 
10. Bergey, D. H., F. C. Harrison, R. S. Breed, B. W Hammer, and F. M. Huntoon (ed.). 1930. Genus If Flavobacterium Bergey et al., 1923, p. 126. In Bergey's manual of determinative bacteriology, 3rd ed. Baillière, Tindall \& Cox, London.

11. Breed, R. S. 1948. Family II. Pseudomonadaceae Winslow et al. Appendix I, p. 178. In R. S. Breed, E. G. D. Murray, and A. Parker Hitchens (ed.), Bergey's manual of determinative bacteriology, 6th ed. Baillière, Tindall \& Cox, London.

12. Breed, R. S. 1955. The families developed from Bacteriaceae Cohn with a description of the family Brevibacteriaceae Breed, 1953. Atti VI Congr. Int. Microbiol. Roma 1:10-15.

13. Breed, R. S. 1957. Genus I. Brevibacterium Breed, 1953, p. 490 . In R. S. Breed, E. G. D. Murray, and N. R. Smith (ed.), Bergey's manual of determinative bacteriology, 7th ed. The Williams \& Wilkins Co., Baltimore.

14. Breed, R. S., E. G. D. Murray, and A. P. Hitchens (ed.). 1948. Appendix to suborder Eubacteriineae, p. 700. In Bergey's manual of determinative bacteriology, 6 th ed. Baillière, Tindall \& Cox, London.

15. Brisou, J. 1955. Microbiologie du milieu marin. Éditions Médicales Flammarion, Paris.

16. Brisou, J. 1958. Contribution à l'étude de la famille des Pseudomonadaceae. A. Baillet, Bordeaux.

17. Brisou, J., C. Tysset, and A. Jacob. 1960. Microflore de l'hépatopancréas de l'écrevisse américaine (Cambarus affinis Say). Arch. Inst. Pasteur Algér. 38:361-370.

18. Buchanan, R. E., and N. E. Gibbons (ed.). 1974. Bergey's manual of determinative bacteriology, 8 th ed. The Williams \& Wilkins Co., Baltimore.

19. Buchanan, R. E., J. G. Holt, and E. F. Lessel, Jr. 1966. Index bergeyana. E. \& S. Livingstone Ltd., London.

20. Buck, J. D., S. P. Meyers, and E. Leifson. 1963. Pseudomonas (Flavobacterium) piscicida Bein comb. nov. J. Bacteriol. 86:1125-1126.

21. Callies, E., and W. Mannheim. 1978. Classification of the Flavobacterium-Cytophaga complex on the basis of respiratory quinones and fumarate respiration. Int. J. Syst. Bacteriol. 28:14-19.

22. Campbell, L. L., Jr., and O. B. Williams. 1951. A study of chitin-decomposing micro-organisms of marine origin. J. Gen. Microbiol, 5:894-905.

23. Carty, C. E., and C. D. Litchfield. 1978. Characterization of a new marine sedimentary bacterium as Flavobacterium oceanosedimentum sp. nov. Int. J. Syst. Bacteriol. 28:561-566.

24. Christensen, P. 1977. Synonymy of Flavobacterium pectinovorum Dorey with Cytophaga johnsonae Stanier. Int. J. Syst. Bacteriol. 27:122-132.

25. Christensen, P. J. 1977. The history, biology, and taxonomy of the Cytophaga group. Can. J. Microbiol. 23: 1599-1653.

26. Conn, H. J. 1919. Ammonification of manure in soil. II. Taxonomic study of two important soil ammonifiers. J. Agric. Res. 16:333-350.

27. Delaporte, B., and P. Daste. 1956. Une bactérie du sol capable de décomposer la fraction fixe de certaines oléorésines Flavobacterium resinovorum n. sp. C.R. Acad. Sci. 242:831-834.

28. Dorey, M. J. 1959. Some properties of a pectolytic soil Flavobacterium. J. Gen. Microbiol. 20:91-104.

29. Elazari-Volcani, B. 1957. Genus XII. Halobacterium Elazari-Volcani, 1940, p. 207. In R. S. Breed, E. G. D. Murray, and N. R. Smith (ed.), Bergey's manual of determinative bacteriology, 7th ed. The Williams \& Wilkins Co., Baltimore.

30. Ferrari, A., and E. Zannini. 1958. Ricerche sulle specie del genere Flavobacterium. Ann. Microbiol. 8:138-204.

31. Follett, E. A. C., and D. M. Webley. 1965. An electron microscope study of the cell surface of Cytophaga john. sonii and some observations on related organisms. Antonie van Leeuwenhoek J. Microbiol. Serol. 31:361-382.
32. Frankland, G. C., and P. F. Frankland. 1889. Ueber einige typische Mikroorganismen im Wasser und im Boden. Z. Hyg. 6:373-400.

33. Gibbons, N. E. 1974. Genus I. Halobacterium ElazariVolcani 1957, p. 270. In R. E. Buchanan and N. E. Gibbons, (ed.), Bergey's manual of determinative bacteriology, 8th ed. The Williams \& Wilkins Co., Baltimore.

34. Harrison, F. C. 1929. The discoloration of halibut. Can. J. Res. 1:214-239.

35. Hayes, P. R. 1963. Studies on marine flavobacteria. J. Gen. Microbiol. 30:1-19.

36. Hayes, P. R. 1977. A taxonomic study of flavobacteria and related Gram negative yellow pigmented rods. $J$. Appl. Bacteriol. 43:345-367.

37. Hayes, P. R., A. P. D. Wilcock, and J. H. Parish. 1977. Deoxyribonucleic acid base composition of flavobacteria and related Gram negative yellow pigmented rods. J. Appl. Bacteriol. 43:111-115.

38. Haynes, W. C. 1957. Genus I. Pseudomonas Migula, 1894, p. 89. In R. S. Breed, E. G. D. Murray, and N. R. Smith (ed.), Bergey's manual of determinative bacteriology, 7th ed. The Williams \& Wilkins Co., Baltimore.

39. Holmes, B., R. J. Owen, Andrea Evans, H. Malnick, and W. R. Willeox. 1977. Pseudomonas paucimobilis, a new species isolated from human clinical specimens, the hospital environment, and other sources. Int. J. Syst. Bacteriol. 27:133-146.

40. Holmes, B., J. J. S. Snell, and S. P. Lapage. 1977 Revised description, from clinical isolates, of Flavobacterium odoratum Stutzer and Kwaschnina 1929, and designation of the neotype strain. Int. J. Syst. Bacteriol. 27:330-336.

41. Holmes, B., J. J. S. Snell, and S. P. Lapage, 1978 Revised description, from clinical strains, of Flavobac terium breve (Lustig) Bergey et al. 1923 and proposal of the neotype strain. Int. J. Syst. Bacteriol. 28:201-208.

42. Holmes, B., J. J. S. Snell, and S. P. Lapage. 1979 Flavobacterium odoratum: a species resistant to a wide range of antimicrobial agents. J. Clin. Pathol. 32:73-77.

43. Jensen, H. L. 1934. Studies on saprophytic mycobacteria and corynebacteria. Proc. Linn. Soc. N.S.W. 59:19-61.

44. King, E. O. 1959. Studies on a group of previously unclassified bacteria associated with meningitis in infants Am. J. Clin. Pathol. 31:241-247.

45. Lapage, S. P., and R. J. Owen. 1973. Flavobacterium meningosepticum from cases of meningitis in Botswana and England. J. Clin. Pathol. 26:747-749.

46. Lapage, S. P., P. H. A. Sneath, E. F. Lessel, V. B. D. Skerman, H. P. R. Seeliger, and W. A. Clark (ed.). 1975. International code of nomenclature of bacteria. American Society for Microbiology, Washington, D.C.

47. Leifson, E. 1962. The bacterial flora of distilled and stored water, III. New species of the genera Corynebacterium, Flavobacterium, Spirillum and Pseudomonas. Int. Bull. Bacteriol. Nomencl. Taxon. 12:161-170.

48. Lelliott, R. A. 1974. Genus XII. Erwinia Winslow, Broad hurst, Buchanan, Krumwiede, Rogers and Smith 1920, p. 332. In R. E. Buchanan and N. E. Gibbons (ed.), Bergey's manual of determinative bacteriology, 8 th ed. The Williams \& Wilkins Co., Baltimore.

49. Levine, M., and L. Soppeland. 1926. Bacteria in creamery wastes. Bull. Iowa State Coll. Agric. Mech. Arts Eng. Exp. Sta. 77:1-72.

50. Lochhead, A. G. 1955. Brevibacterium helvolum (Zim mermann) comb. nov. Int. Bull. Bacteriol. Nomencl. Taxon. 5:115-119.

51. Loginova, L. G., G. B. Userbayeva, and L. A. Egorova. 1978. A new species of the obligate thermophilic bacterium Flavobacterium thermophilum sp. nov. Mikrobiologiya 47:1081-1085.

52. Lund, B. M. 1969. Properties of some pectolytic, yellow pigmented, Gram negative bacteria isolated from fresh cauliflowers. J. Appl. Bacteriol. 32:60-67. 
53. Lustig, A. 1890. Diagnostica dei batteri delle acque con una guida alle ricerche batteriologiche e microscopiche. Rosenberg \& Sellier, Torino.

54. Marini, F., and C. Spalla. 1964. Un nuovo fattore di crescita per un batterio marino (Flavobacterium tirren. icum n. sp.) presente nella farina di pesce e prodotto da microrganismi. Giorn. Microbiol. 12:35-44.

55. McMeekin, T. A., and J. M. Shewan. 1978. Taxonomic strategies for Flavobacterium and related genera. J. Appl. Bacteriol. 45:321-332.

56. McMeekin, T. A., J. T. Patterson, and J. G. Murray. 1971. An initial approach to the taxonomy of some Gram-negative, yellow pigmented rods. J. Appl. Bacteriol. 34:699-716.

57. McMeekin, T. A., D. B. Stewart, and J. G. Murray. 1972. The Adansonian taxonomy and the deoxyribonucleic acid base composition of some Gram negative, yellow pigmented rods. J. Appl. Bacteriol. 35:129-137.

58. Millar, W. N. 1973. Heterotrophic bacterial population in acid coal mine water: Flavobacterium acidurans sp. n. Int. J. Syst. Bacteriol. 23:142-150.

59. Mitchell, T. G., M. S. Hendrie, and J. M. Shewan. 1969. The taxonomy, differentiation and identification of Cytophaga species. J. Appl. Bacteriol. 32:40-50.

60. Olsen, H. 1969. Flavobacterium meningosepticum isolated from outside hospital surroundings and during routine examination of patient specimens. Acta Pathol. Microbiol. Scand. 75:313-322.

61. Owen, R. J., and S. P. Lapage. 1974. A comparison of strains of King's group IIb of Flavobacterium with Flavobacterium meningosepticum. Antonie van Leeuwenhoek J. Microbiol. Serol. 40:255-264.

62. Owen, R. J., and J. J. S. Snell. 1973. Comparison of group IIf with Flavobacterium and Moraxella. Antonie van Leeuwenhoek J. Microbiol. Serol. 39:473-480.

63. Owen, R. J., and J. J. S. Snell. 1976. Deoxyribonucleic acid reassociation in the classification of flavobacteria. J. Gen. Microbiol. 93:89-102.

64. Payza, A. N., and E. D. Korn. 1956. The degradation of heparin by bacterial enzymes. I. Adaptation and lyophilized cells. J. Biol. Chem. 223:853-858.

65. Perry, L. B. 1973. Gliding motility in some non-spreading flexibacteria. J. Appl. Bacteriol. 36:227-232.

66. Pickett, M. J., and C. R. Manclark. 1970. Nonfermentative bacilli associated with man. I. Nomenclature. Am. J. Clin. Pathol. 54:155-163.

67. Priest, F. G., H. J. Somerville, J. A. Cole, and J. S. Hough. 1973. The taxonomic position of Obesumbac. terium proteus, a common brewery contaminant. J. Gen. Microbiol. 75:295-307.

68. Shimwell, J. L. 1963. Obesumbacterium gen. nov. Brew. J. 99:759-760.

69. Shimwell, J. L., and M. Grimes. 1936. The distinguishing characters of Flavobacterium proteum (sp. nov.), the common rod bacterium of brewers' yeast. J. Inst.
Brew. 42:348-350.

70. Sickles, G. M., and M. Shaw. 1934. A systematic study of microörganisms which decompase the specific carbohydrates of the pneumococcus. J. Bacteriol. 28:415431.

71. Sneath, P. H. A., and V. B. D. Skerman. 1966. A list of type and reference strains of bacteria. Int. J. Syst. Bacteriol. 16:1-133.

72. Soppeland, L. 1924. Flavobacterium suaveolens, a new species of aromatic bacillus isolated from dairy wastes. J. Agric. Res. 28:275-276.

73. Stanier, R. Y. 1943. A note on the taxonomy of Proteus hydrophilus. J. Bacteriol. 46:213-214.

74. Steinhaus, E. A. 1941. A study of the bacteria associated with thirty species of insects. J. Bacteriol. 42:757-790.

75. Stutzer, M., and A. Kwaschnina. 1929. In Aussaaten aus den Fäzes des Menschen gelbe Kolonien bildende Bakterien (Gattung Flavobacterium u.a.). Zentralbl. Bakteriol. Parasitenkd. Infektionskr. Hyg. Abt. I. Orig. 113:219-225.

76. Tatum, H. W., W. H. Ewing, and R. E. Weaver. 1974. Miscellaneous gram-negative bacteria, p. 270. In E. H. Lennette, E. H. Spaulding, and J. P. Truant (ed.), Manual of clinical microbiology, 2nd ed. American Society for Microbiology, Washington, D.C.

77. von Graevenitz, A., and M. Grehn. 1977. Susceptibility studies on Flavobacterium II-b. FEMS Microbiol. Lett. 2:289-292.

78. Waksman, S. A., and A. T. Henrici. 1948. Genus $I$. Nocardia Trevisan, p. 892. In R. S. Breed, E. G. D. Murray, and A. Parker Hitchens (ed.), Bergey's manual of determinative bacteriology, 6th ed. Baillière, Tindall \& Cox, London.

79. Weeks, O. B. 1955. Flavobacterium aquatile (Frankland and Frankland) Bergey et al., type species of the genus Flavobacterium. J. Bacteriol. 69:649-658.

80. Weeks, O. B. 1974. Genus Flavobacterium Bergey et al., 1923, p. 357. In R. E. Buchanan and N. E. Gibbons (ed.), Bergey's manual of determinative bacteriology, 8th ed. The Williams \& Wilkins Co., Baltimore.

81. Weeks, O. B., and S. M. Beck. 1960. Nutrition of Flavobacterium aquatile strain Taylor and a microbiological assay for thiamine. J. Gen. Microbiol. 23:217-229.

82. Weeks, O. B., and R. S. Breed. 1957. Genus III. Flavobacterium Bergey et al., 1923, p. 309. In R. S. Breed, E. G. D. Murray, and N. R. Smith (ed.), Bergey's manual of determinative bacteriology, 7 th ed., The Williams \& Wilkins Co., Baltimore.

83. Zimmermann, O. E. R. 1890. Die Bakterien unserer Trink- und Nutzwässer, insbesondere des Wassers der Chemnitzer Wasserleitung. Elfter Bericht. Naturwiss. Ges. Chemnitz., p. 53-154.

84. ZoBell, C. E., and H. C. Upham. 1944. A list of marine bacteria including descriptions of sixty new species. Bull. Scripps Inst. Oceanogr. 5:239-292. 